\title{
Extrafloral nectary-the sleeping beauty of plant science
}

\author{
CHEN Xiaoya
}

\begin{abstract}
Cotton is one of the most important cash crops, its growth season coincides with a high incidence of diverse groups of pests, leading to heavy use of pesticides. Recent identification of a signaling protein as a candidate regulator of cotton extrafloral nectary provides a new insight into the formation of sophisticated defense mechanisms in plants.
\end{abstract}

Keywords: Extrafloral nectary, PB1 domain, GaNEC1I, Cotton, Gossypium, Indirect defense, Insect

\section{Main text}

Extrafloral nectary is an indirect defense device of plants and can be located on the shoot, leaf stalks, leaf blades or stipules, or on the inner or outer surfaces of the sepals but not involved in pollination (Heil 2011). However, its formation in crops and potential role in biocontrol of pests and diseases are under studied (Stenberg et al. 2015). Nectar, a sweet aqueous secretion consisting of sugars, amino acids and secondary metabolites, mediates the interactions of plants with pollinators and defenders (Heil 2011). More than 100 angiosperm species including cotton (Gossypium spp.) produce extrafloral nectaries to attract mutualistic animals to catch herbivores. The exists of extrafloral nectarines in cotton speices are slightly different, since G. gossypiodes (D6) and allotertraploid G. tomentosum (AD3) have no nectarines on the midribs of leaves ( $\mathrm{Hu}$ et al. 2020). Cotton accessions with variations in extrafloral nectaries, combined with the progresses in cotton genomics ( $\mathrm{Li}$ et al. 2015; $\mathrm{Hu}$ et al. 2015; $\mathrm{Li}$ et al. 2017; Du et al. 2018; Ma et al. 2018; Yang et al. 2019; Yang et al. 2020; Zhang et al. 2015) provide an unprecedented opportunity to elucidate the genetic basis of nectar formation and ecological functions. Recently, Li, Yang and colleagues from Institute of Cotton Research of Chinese Academy of Agricultural Sciences, identified the causal quantitative trait locus (QTL)/gene for the cotton extrafloral nectary and revealed the genomic

\footnotetext{
Correspondence: xychen@sibs.ac.cn
}

CAS Center for Excellence in Molecular Plant Sciences/Shanghai Institute of Plant Physiology and Ecology, Chinese Academy of Sciences, 300 Fenglin Road, Shanghai 200032, China differences in the causal QTL regions as well as the potential network regulating nectary formation (Hu et al. 2020). Uncovered molecular details about nectary formation could be applied to molecular breeding of cultivars that confer pestresistance via biological control.

Through investigating the extrafloral distribution in 27 different species, $\mathrm{Hu}$ et al. found that the nectary was present in the common ancestor of Kokia and Gossypium. The nectariless trait was thus derived from natural mutation. Based on a core collection of 215 G. arboreum accessions, they compared the extrafloral nectarybearing to the nectariless accessions and found a region of Chr12 showing strong differentiation and overlapping with the QTL region identified via genome-wide analysis. They further narrowed the candidate genes to a 96 $\mathrm{kb}$ region using an $\mathrm{F}_{2}$ population, and validated GaNEC1, encoding a Phox-Bem1 (PB1) domaincontaining protein, as a regulator of nectary formation. They found that a deletion of five amino acids, together with a nonsynonymous substitution, probably caused structural alteration in the GaNEC1 protein and confer the nectariless phenotype. Silencing of GaNEC1 led to a smaller foliar nectary phenotype. Further, they found that the jasmonate (JA) related genes were up-regulated and the cell wall genes were down-regulated in the nectary. They also performed metabolomics analysis of the nectary secretion and identified more than 400 nectar components, including the expected saccharides and amino acids. 
The PB1 domain is conserved in eukaryotes and modulates protein interactions. Identification of a PB1 domaincontaining protein as a regulatory component of the extrafloral nectary formation and sheds a light on the molecular mechanism underlying the evolution and development of this adaptive sweet apparatus and can be an important progress in this filed. Hopefully the finding will stimulate further investigation of various aspects of nectaries in flowers and other parts, which will help develop environmentally friendly, healthy and beautiful strategies for pests control.

\section{Acknowledgments}

The author thanks Dr. LIU Ningjing and WANG Lingjian for critical reading of the manuscript.

\section{Author's contributions}

CHEN XY prepared and wrote the manuscript. The author read and approved the final manuscript.

\section{Funding}

Not applicable.

\section{Availability of data and materials}

No other data related to this study is available at this time.

Ethics approval and consent to participate

Not applicable.

\section{Consent for publication}

Not applicable.

\section{Competing interests}

The authors declare that they have no competing interests.

Received: 27 February 2020 Accepted: 12 March 2020

\section{.}

\section{References}

Du X, Huang G, He S, et al. Resequencing of 243 diploid cotton accessions based on an updated a genome identifies the genetic basis of key agronomic traits. Nat Genet. 2018;50:796-802. https://doi.org/10.1038/s41588-018-0116-x.

Heil M. Nectar: generation, regulation and ecological functions. Trends Plant Sci. 2011;16:191-200. https://doi.org/10.1016/j.tplants.2011.01.003.

Hu G, Koh J, Yoo MJ, et al. Gene-expression novelty in allopolyploid cotton: a proteomic perspective. Genetics. 2015;200(1):91-104. https://doi.org/10.1534/genetics.115.174367.

Hu W, Qin W, Jin Y, et al. Genetic and evolution analysis of extrafloral nectary in cotton. Plant Biotechnol J. 2020. https://doi.org/10.1111/pbi.13366.

Li F, Fan G, Lu C, et al. Genome sequence of cultivated upland cotton (Gossypium hirsutum TM-1) provides insights into genome evolution. Nat Biotechnol. 2015;33:524-30. https://doi.org/10.1038/nbt.3208.

Li F, Yang Z, Wang Z, Yang Z. Genome sequencing brought Gossypium biology research into a new era. Sci China Life Sci. 2017;60:1463-6. https://doi.org/10. 1007/s11427-017-9233-5.

Ma Z, He S, Wang X, et al. Resequencing a core collection of upland cotton identifies genomic variation and loci influencing fiber quality and yield. Nat Genet. 2018;50:796-802. https://doi.org/10.1038/s41588-018-0119-7.

Stenberg JA, Heil M, Åhman I, et al. Optimizing crops for biocontrol of pests and disease. Trends Plant Sci. 2015;20:698-712. https://doi.org/10.1016/j.tplants.2015.08.007.

Yang Z, Ge X, Yang Z, et al. Extensive intraspecific gene order and gene structural variations in upland cotton cultivars. Nat Commun. 2019;10:298913. https://doi.org/10.1038/s41467-019-10820-x.

Yang Z, Qanmber G, Wang Z, et al. Gossypium genomics: trends, scope, and utilization for cotton improvement. Trends Plant Sci. 2020. https://doi.org/10. 1016/j.tplants.2019.12.011.

Zhang T, Hu Y, Jiang W, et al. Sequencing of allotetraploid cotton (Gossypium hirsutum L. acc. TM-1) provides a resource for fiber improvement. Nat Biotechnol. 2015;33:531-7. https://doi.org/10.1038/nbt.3207.

Ready to submit your research? Choose BMC and benefit from:

- fast, convenient online submission

- thorough peer review by experienced researchers in your field

- rapid publication on acceptance

- support for research data, including large and complex data types

- gold Open Access which fosters wider collaboration and increased citations

- maximum visibility for your research: over $100 \mathrm{M}$ website views per year

At $\mathrm{BMC}$, research is always in progress.

Learn more biomedcentral.com/submissions 